\begin{tabular}{|l|l|l|}
\hline \multicolumn{2}{|c|}{ PublisherInfo } \\
\hline \hline PublisherName & $:$ & BioMed Central \\
\hline \hline PublisherLocation & $:$ & London \\
\hline \hline PublisherImprintName & $:$ & BioMed Central \\
\hline \hline
\end{tabular}

\title{
Noninvasive ventilation for the immunosuppressed patient?
}

\begin{tabular}{|l|l|l||}
\hline \multicolumn{2}{|c||}{ ArticleInfo } \\
\hline \hline ArticleID & $:$ & 4300 \\
\hline \hline ArticleDOI & $:$ & $10.1186 /$ ccf-2001-73252 \\
\hline \hline ArticleCitationID & $:$ & 73252 \\
\hline \hline ArticleSequenceNumber & $:$ & 11 \\
\hline \hline ArticleCategory & $:$ & Paper Report \\
\hline \hline ArticleFirstPage & $:$ & 1 \\
\hline \hline ArticleLastPage & $:$ & 3 \\
\hline \hline & & RegistrationDate : 2001-12-4 \\
ArticleHistory & $:$ & Received \\
\hline ArticleCopyright & $:$ 2001-3-28 \\
\hline \hline ArticleGrants & $:$ & Biomed Central Ltd2001 \\
\hline \hline ArticleContext & $:$ & 1305455 \\
\hline \hline
\end{tabular}




\section{Keywords}

Haematological malignancy, immunosuppression, noninvasive ventilation, outcome, respiratory failure

\section{Context}

Intubation and mechanical ventilation for respiratory failure in the immunosuppressed patient has a mortality rate ranging from 60 to $100 \%$. Aggressive measures to avoid intubation may, therefore, improve outcome in these patients and avoid invasive therapy, which is often futile. Noninvasive ventilation (NIV) at an early stage in the respiratory failure of these patients may achieve this goal. This trial compares the efficacy of NIV with standard medical therapy.

\section{Significant findings}

Requirement for intubation, complications, and ICU and hospital mortality were significantly better in those patients receiving early NIV. Hospital mortality was $50 \%$ and $81 \%(\mathrm{P}=0.02)$ for the NIV and conventional groups, respectively. Patients who required intubation and mechanical ventilation in either group, had a $100 \%$ mortality. In the immunocompromised, initiation of NIV early in the course of hypoxic respiratory failure prevents intubation, reduces complications, and thereby improves survival.

\section{Comments}

Despite the small numbers involved in this trial, the findings are powerful and important. The futility of invasive ventilation in this patient population has long been recognised $3 / 4$ as they succumb to nosocomial pneumonia. However, support during the hypoxic period, which avoids the lethal complications of nosocomial infection to which they are so prone may buy time to allow life-saving therapies, such as antibiotics, to work. NIV appears to buy this time, although it may be that a simpler form of ventilatory support (continuous positive airway pressure [CPAP]) is as effective and should be the subject of future research. However, to date trials in immunocompetent patients have so far shown that CPAP is no better than conventional oxygen therapy in supporting respiratory failure. Although 
NIV clearly appears to improve outcome in these patients, failure of NIV resulting in intubation equates to a fatal outcome. This implies that treatment of the cause of the respiratory failure (eg with antibiotics) has failed and so further supportive measures, such as invasive ventilation, may be futile.

\section{Methods}

Prospective randomised controlled trial of noninvasive ventilation versus conventional medical treatment in immunosuppressed patients (26 in each group) with early hypoxaemic respiratory failure.

\section{Additional information}

Related editorial

Hill NS: Noninvasive ventilation for immunocompromised patients. New Engl J Med 2001, 344:522-523.

\section{References}

1. Hilbert G, Gruson D, Vargas F, Valentino R, Gbikpi-Benissan G, Dupon M, Reiffers J, Cardinaud JP: Noninvasive ventilation in immunosuppressed patients with pulmonary infiltrates, fever, and acute respiratory failure. New Engl J Med . 2001, 344: 481-488.

This PDF file was created after publication. 